\title{
Ischemic cardiovascular disease in workers occupationally exposed to urban air pollution - A systematic review
}

\author{
Paola De Marchis', Maria Gabriella Verso', Fabio Tramuto², Emanuele Amodio², Diego Picciotto' \\ 'Department of Sciences for Health Promotion and Mother-Child Care, 'G. D'Alessandro', Occupational Health Section, \\ University of Palermo, Italy \\ 2 Department of Sciences for Health Promotion and Mother-Child Care, 'G. D'Alessandro', Hygiene Health Section, \\ University of Palermo, Italy
}

De Marchis P, Verso MG, Tramuto F, Amodio E, Picciotto D. Ischemic cardiovascular disease in workers occupationally exposed to urban air pollution - A systematic review. Ann Agric Environ Med. 2018; 25(1): 162-166. doi: 10.26444/aaem/79922

\begin{abstract}
Introduction. Cardiovascular disease is the first cause of morbidity and mortality worldwide. Among several known risk factors, researchers also focus their attention on the chronic exposure to air pollution. There is much evidence that exposure to air pollution, especially to ultrafine particles, can damage the endothelium and can favour cardiovascular diseases in the general population. Occupational exposition could be an additive risk factor for the cardiovascular system. This article presents a scientific review of the linkage between occupational exposure to air pollution and ischemic heart disease.

Materials and method. A scientific review was undertaken, followed by PRISMA Statements. Observational studies were selected from several scientific databases, likesuch as Pubmed, Google Scholar, Nioshtic-2 and Reserchgate, searching for selected key words: police workers, professional drivers, mail carriers, filling station attendants, road cleaners, garage workers, motor vehicles and engine maintenance. All the key words were combined with "Boolean Operators" with the following words: cardiovascular (or cardiac) disease, cardiovascular function, cardiovascular system, ischemic heart disease, coronary disease, myocardial infarction. During the systematic research, the focus was on retrospective and prospective studies from January 1990 - December 2014.

Results. Both the retrospective and prospective studies showed an increased risk of ischemic heart disease in occupationally occupied people exposed to air pollution. Only one study presented a ly minor risk.

Conclusions. The findings of this systematic review suggest a possible linkage between occupational exposure to urban air pollution, especially to motor exhaust and particulate, and ischemic heart disease.
\end{abstract}

\section{Key words}

air pollution, infarction, cardiovascular

\section{INTRODUCTION}

The research showed that during the last two decades, exposure to urban pollution could have increased cardiovascular morbidity and mortality, particularly in people already at risk for these conditions. It is not completely clear how the acute and chronic exposure to air pollution, and especially to particulate matter (fine and ultrafine particles: PM 10, PM 2,5), can damage the cardiopulmonary system. There are various hypothesized pathophysiological mechanisms. The PM inhaled could activate an inflammatory process with systemic oxidative stress, increasing the expression of inducibile nitric oxide synthase (iNOS) and cyclooxygenase-2 as pro-atherogenic factors. Other pathways are characterized by the induction by PM inhaled of an alteration of the balance of the autonomic nervous system [1-5]. These mechanisms are probably mediated by epigenetic phenomena. Many studies observed that microRNAs (miRNAs), transferred between cells by extracellular vescicles (EVs), may play an important role in PM-induced cardiovascular risk. Other studies have investigated the role of DNA methylation in air pollution

Address for correspondence: Paola De Marchis, Department of Sciences for Health Promotion and Mother-Child Care, 'G. D'Alessandro', Occupational Health Section, University of Palermo, Italy

e-mail:dr.demarchis@gmail.com,

Received: 19 December 2016; accepted: 18 May 2017; first published on July 10, 2017 induced cardiovascular diseases. Platelet mitochondrial DNA methylation, for example, is an energy source for platelet function and it could explain, in part, the role of these cells in cardiovascular diseases [6-9].

Although many studies on the general population show an association between exposure to PM derived from urban pollution and cardiovascular disease, few researchers have focused their attention on the occupational exposures.

Many job categories are subjected to urban air pollution, and they are subdivided into two groups: exposed to motor exhaust outdoors: police and traffic officers, all professional drivers, filling station attendants, and many others, and those most frequently exposed to motor exhaust indoors: garages workers, construction and machine repair operators, etc. Worldwide, millions of workers are occupationally exposed to air pollution, and the constancy of this exposition may represent a cardiovascular risk [10, 11].

The aim of the present study is a systematic review of the scientific literature concerning occupational exposures to urban air pollution and cardiovascular disease, with particular attention to ischemic heart disease and infarction, using PRISMA statements [12]. 


\section{MATERIALS AND METHOD}

Search strategy. Observational studies investigating the association between urban air pollution occupational exposures and ischemic heart disease, including both clinical and intermediate outcomes were selected from several scientific databases, like Pubmed, Google Scholar, Nioshtic-2, Reserchgate.

A search was made for key words: police employees, including police officers, policemen, traffic wardens), professional drivers (including bus drivers, taxi drivers), street vendors (also shop vendors, newspaper vendors), mail carriers (postmen, postal workers), filling station attendants, road cleaners, garage workers, motor vehicle and engine maintenance workers. All the key words were combined with "Boolean Operators" with the following words: cardiovascular (or cardiac) disease, cardiovascular function, cardiovascular system, ischemic heart disease, coronary disease and myocardial infarction.

During the systematic research, the focus was on retrospective and prospective studies investigating occupationally-exposed people, published in the English language, from January 1990 - December 2014, and encompassed literature of the last 25 years. Secondary references were also used, cited by articles identified in the first search. Only full text publications were used and included studies where the authors investigated multiple outcomes, not only cardiovascular or ischemic cardiac disease. But in every articles selected, the ischemic heart disease was statistically evaluated, including mortality and incidence of new cases. Clinical outcomes were also identified referring to the International Code Disease version 10 (ICD $10)$ and using ICD (I20-I25).

Studies were excluded if the exposure to air pollution was not derived from motor exhausts or from urban sources, e.g. industrial emissions, as well as articles that did not contain original research, animal and experimental studies and case reports. Selection of the articles was conducted by an initial screening of titles, abstracts of the articles that fitted the criteria for inclusion, and finally, if the abstract was interesting, the full text was obtained and examined. Because of the small number of studies available for meta-analyses, the results of the studies are illustrated in a forest plot and subsequently simply commented on.

Data extraction. For each study responding to the criteria for elegibility, much information was extracted using one Table for data extractions, based on the template of the Cochrane Consummers and Communication Review Group. Information wa collected about the study characteristics (author(s), year and country of publication, study protocol), population characteristics (age, gender, occupational exposition), outcomes and statistical method for evaluating the strength of the association between the study outcomes and the occupational exposure to urban pollution. Statistical association was evaluated using the relative risk (RR) for prospective studies and the odds ratio $(\mathrm{OR})$ for retrospective studies. If several RRs were found for different outcomes, the outcome of specific interest was selected. In particular, only the risk measures for occupational exposition to urban pollution and ischemic heart disease (ICD-10 I20-I25) were selected.

\section{RESULTS}

Literature search. The literature search identified 589 citations, of which a large number, after reading the title or the abstract, were immediately excluded because they did not adhere to the criteria for the presented review. The full text of 48 articles were examined and 39 articles. Finally, 9 studies were included in the review (Fig. 1).

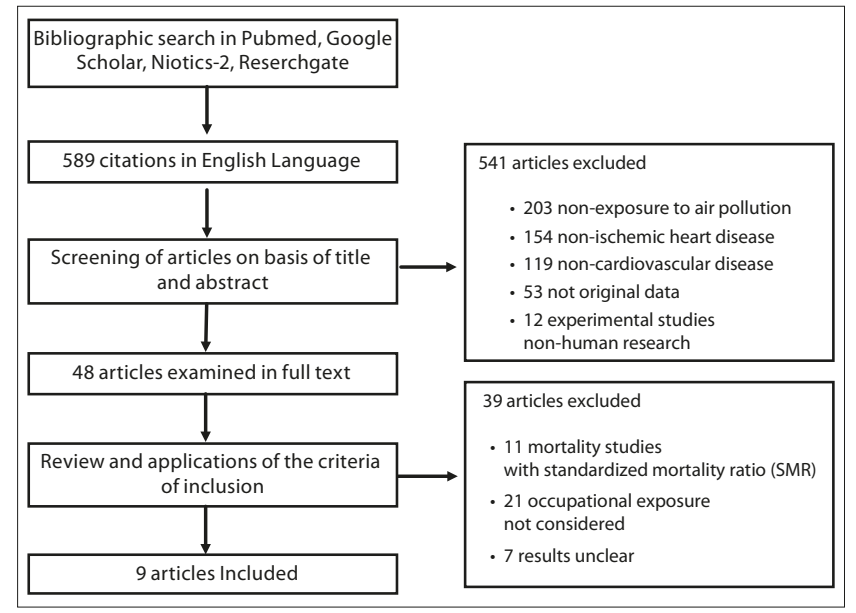

Figure 1. Flow chart of study selection.

Study Characteristics. Study characteristics of each of the 9 studies are presented in Table 1. Six studies were prospective, the others were retrospective. All the studies but one examined professional drivers, in comparison with others jobs. One study [13] evaluated occupational exposure to asphalt fumes. All but 2 of the selected studies had a specific endpoint incidence of ischemic heart disease. In the two cases with several endpoints, only the results about ischemic cardiovascular disease were considered. Where the results were extrapolated for single professional exposure, the single risk index for every typology of professional drivers (taxi drivers, lorry and truck drivers, bus drivers) were recorded [14-16].

In two studies [17, 18], the results for professional exposure to motor exhausts were extracted, excluding the other occupational expositions because they were not in accord with the present study. All the studies used an external reference group, mostly from the general population or from other occupational groups, for statistical comparison.

Effect estimates of prospective studies. Effects estimates varied widely across the studies. The relative risk (RR) ranged from 0.92 [15] and 1.64 [13] for ischemic heart disease, and specifically infarction, with the most positive association observed for professional drivers exposed to motor exhaust. All the studies had statistically corrected results for tobacco smoke and for the major risk factors of cardiovascular disease. Only in one study the RR was less than one. This study observed the association between myocardial infarction and the occupation of subway drivers in Sweden, considering the occupational exposure of these workers to particulate (PM10). In this case, although very high levels of particulate in the size range 1-10 $\mu \mathrm{m}$ were found in the air of the underground platforms, drivers spent only a small part of their work time on the platforms [20]. 
Table 1. Study characteristics. RR - Relative Risk; OR - Odds Ratio; Cl - Confidential Interval

\begin{tabular}{|c|c|c|c|c|c|}
\hline Study & Country & Population and sample size & Exposure & Outcomes investigates & Main results \\
\hline $\begin{array}{l}\text { Rosengren, } \\
1991 \text { [16] }\end{array}$ & Sweden & $\begin{array}{l}\text { Bus and tram drivers }(n=103) \\
\text { taxi drivers }(n=56), \text { Lorry drivers } \\
(n=158)\end{array}$ & Air pollution & $\begin{array}{l}\text { Incidence of coronary } \\
\text { heart disease }\end{array}$ & $\begin{array}{l}\text { Bus and tram drivers: OR } 3.3-\text { C.I. } 95 \% \\
(2.0-5.5) ; \text { Taxi drivers: OR } 3.1 \text { - C.I. } 95 \% \\
(1.6-6.2) ; \text { Lorry drivers: OR 1.2- C.I. } 95 \% \\
(0.6-2.1)\end{array}$ \\
\hline $\begin{array}{l}\text { Alfredsson, } \\
1993[19]\end{array}$ & Sweden & Bus drivers $(n=334)$ & $\begin{array}{l}\text { Automobile exhaust } \\
\text { fumes }\end{array}$ & $\begin{array}{l}\text { Incidence of myocardial } \\
\text { infarction in Stockolm. } \\
\text { Mortality for cancer }\end{array}$ & $\begin{array}{l}\text { Myocardial infarction: RR 1.6-C.I. 95\% } \\
(1.1-1.9)\end{array}$ \\
\hline $\begin{array}{l}\text { Gustavsson, } \\
1996[15]\end{array}$ & Sweden & $\begin{array}{l}\text { Urban professional drivers (taxi } \\
\text { and bus drivers) ( } \mathrm{n}=211 \text { bus } \\
\text { drivers; } \mathrm{n} \\
=297 \text { taxi drivers) }\end{array}$ & Motor exhaust fumes & $\begin{array}{l}\text { Incidence of myocardial } \\
\text { infarction }\end{array}$ & $\begin{array}{l}\text { Taxi drivers: RR 1.65-C.I. 95\% (1.30-2.11) } \\
\text { Bus drivers: RR 1.53-C.I. 95\% (1.15-2.05) }\end{array}$ \\
\hline $\begin{array}{l}\text { Gustavsson, } \\
2001[17]\end{array}$ & Sweden & $\begin{array}{l}\text { Occupationally exposed to } \\
\text { motor exhaust }(n=429)\end{array}$ & Motor exhaust fumes & $\begin{array}{l}\text { Incidence of myocardial } \\
\text { infarction }\end{array}$ & RR 1.21-C.I. 95\% (0.92-1.59) \\
\hline $\begin{array}{l}\text { Bigert, } \\
2003[14]\end{array}$ & Sweden & $\begin{array}{l}\text { Bus drivers }(n=77) \text {, taxi drivers } \\
(n=78) \text {, truck drivers }(n=179)\end{array}$ & Motor exhaust fumes & $\begin{array}{l}\text { Incidence of myocardial } \\
\text { infarction }\end{array}$ & $\begin{array}{l}\text { Bus drivers: OR 2.41-C.I. 95\% (1.15-5.06); } \\
\text { taxi drivers: OR1.67 - C.I. (0.84-3.31); truck } \\
\text { drivers: OR 1.32 -C.I. } 95 \%(0.86-2.03)\end{array}$ \\
\hline $\begin{array}{l}\text { Burstyn, } \\
2005 \text { [13] }\end{array}$ & $\begin{array}{l}\text { Denmark Finland, } \\
\text { France, Germany Israel, } \\
\text { Netherlands and Norway }\end{array}$ & $\begin{array}{l}\text { Asphalt workers }(\mathrm{n}=12367 \\
\text { males) }\end{array}$ & Asphalt fumes & $\begin{array}{l}\text { Mortality for ischemic } \\
\text { heart disease and } \\
\text { cardiovascular disease }\end{array}$ & RR 1.64 (1.13-2.38) \\
\hline $\begin{array}{l}\text { Bigert, } \\
2007[20]\end{array}$ & Sweden & Subway drivers $(n=54)$ & Airborne particulates & $\begin{array}{l}\text { Incidence of myocardial } \\
\text { infarction }\end{array}$ & RR 0.92 -C.I. 95\% (0.68-1.25) \\
\hline $\begin{array}{l}\text { Toren, } \\
2007[18]\end{array}$ & Sweden & $\begin{array}{l}\text { Construction workers ( } \mathrm{n} \\
=176,309 \text { exposed and } 71,778 \\
\text { unexposed males) }\end{array}$ & $\begin{array}{l}\text { Inorganic dust, } \\
\text { fumes, diesel exhaust, } \\
\text { asphalt fumes, metal } \\
\text { fumes }\end{array}$ & $\begin{array}{l}\text { Incidence of ischemic } \\
\text { heart disease and } \\
\text { cerebrovascular disease }\end{array}$ & RR 1.13 C.I. 95\% (1.07-1.19) \\
\hline $\begin{array}{l}\text { Ilar, } 2014 \\
{[21]}\end{array}$ & Sweden & $\begin{array}{l}\text { Occupational workers exposed } \\
\text { to motor exhaust (professional } \\
\text { drivers, bus garage workers, } \\
\text { construction machine operators) }\end{array}$ & Motor exhaust fumes & $\begin{array}{l}\text { Incidence of myocardial } \\
\text { infarction }\end{array}$ & O.R. 1.21- C.I. 95\% (0.91-1.59) \\
\hline
\end{tabular}

Some authors evaluated the incidence of nonfatal myocardial infarction $[13,15,17,20]$. Two studies $[15,18]$ observed just the incidence of myocardial fatal infarction and only one study observed both the mortality for ischemic heart disease and the incidence of ischemic heart disease [19]. The major of RRs, corresponding to 1.64, with confidential interval (C.I.) $95 \%$ of 1,13-2.38), was found in one study that evaluated the association between professional exposure to polycyclic aromatic hydrocarbons in male asphalt workers from some North Europe countries, and mortality for ischemic heart disease [13]. All the others studies but one, with RR ranging from 1.6-1.13, observed an association between ischemic heart disease and professional drivers, with occupational exposure to motor exhaust. One study examined Swedish construction workers exposed to many pollutants, like inorganic dust, fumes, diesel exhaust, asphalt fumes [18] (Fig. 2, tab. 2).

Effect estimates of retrospective studies. Few retrospective studies were found which had odds ratio (OR) ranging from 1.2-3.3 [16]. Three different results were extracted from one study on the basis of the occupational group: bus drivers, taxi drivers and truck drivers. This study showed a sensible difference between the various occupational groups of drivers, especially between bus and taxi drivers on the one hand, and truck drivers on the other (Tab. 3). From the Bigert study [14] the results were divided on the basis of the occupational group: bus, taxi and truck drivers, with differences in the OR, major for bus and taxi drivers and less for truck drivers (Tab. 3). One study [21] examined several professional groups with. exposure to motor exhaust including: professional drivers, garage workers and mechanics (Fig. 3).

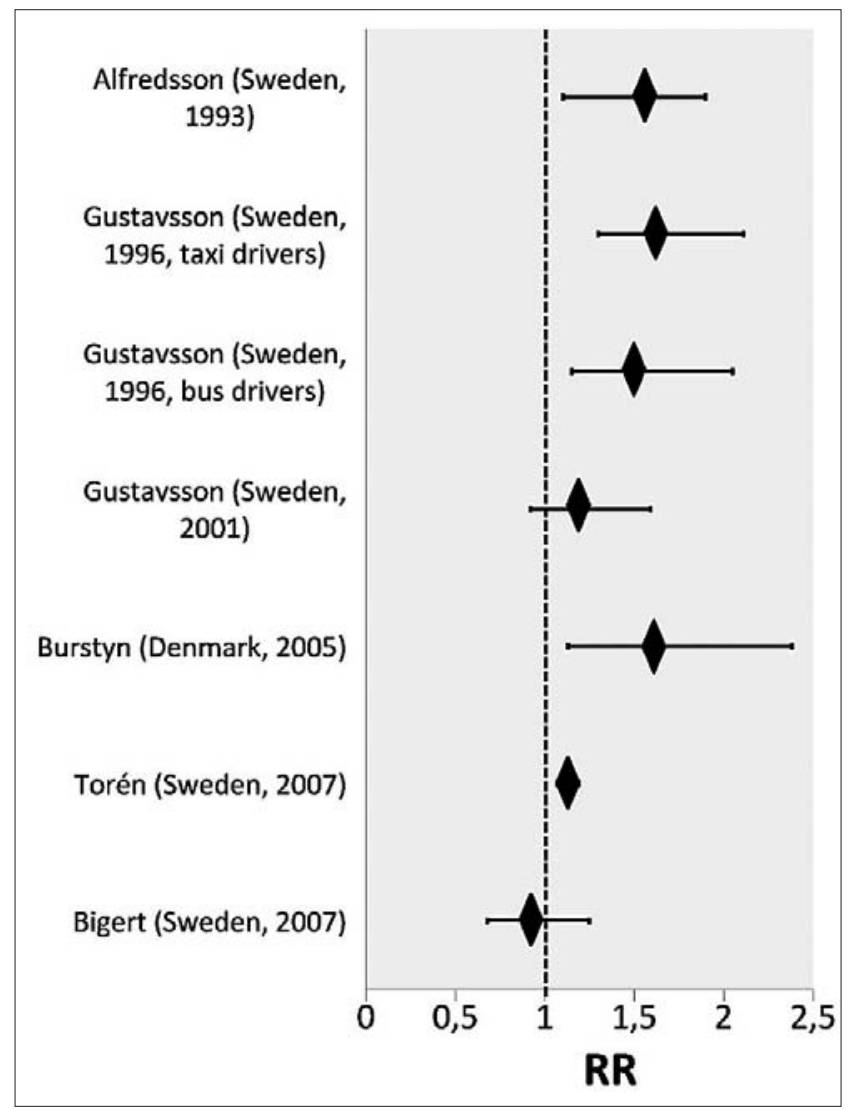

Figure 2. Forest plot of effect estimate of prospective studies. $\mathrm{RR}$ - relative risk 
Table 2. Effect estimate of prospective studies. R.R - Relative Risk; CI - Confidential Interval

\begin{tabular}{|c|c|c|c|c|c|}
\hline Reference & $\begin{array}{l}\text { Occupational } \\
\text { group examined }\end{array}$ & External comparison group & $\begin{array}{l}\text { Population characteristics } \\
\text { standardized to }\end{array}$ & Exposure type & $\begin{array}{l}\text { Incidence of ischemic heart } \\
\text { disease and/or Myocardial } \\
\text { infarction -RR }(95 \% \mathrm{Cl})\end{array}$ \\
\hline $\begin{array}{l}\text { Alfredsson, } \\
1993[19]\end{array}$ & Male bus drivers & Other employed men & $\begin{array}{l}\text { Age, Calendar year and Swedish } \\
\text { County }\end{array}$ & Automobile exhaust fumes & $1.6(1.1-1.9)$ \\
\hline $\begin{array}{l}\text { Gustavsson, } \\
1996[15]\end{array}$ & Male taxi drivers & $\begin{array}{l}\text { Other employed men (white } \\
\text { collar workers, blue collar workers, } \\
\text { unskilled manual workers }\end{array}$ & Age, area of residence & Automobile exhaust fumes & $1.65(1.30-2.11)$ \\
\hline $\begin{array}{l}\text { Gustavsson, } \\
1996[15]\end{array}$ & Male bus drivers & $\begin{array}{l}\text { Other employed men (white } \\
\text { collar workers, blue collar workers, } \\
\text { unskilled }\end{array}$ & Age, area of residence & Automobile exhaust fumes & $1.53(1.1-2.05)$ \\
\hline $\begin{array}{l}\text { Gustavsson, } \\
2001[17]\end{array}$ & $\begin{array}{l}\text { Occupational } \\
\text { exposed to } \\
\text { motor exhaust }\end{array}$ & General population & $\begin{array}{l}\text { Age, sex and year of enrollement } \\
\text { and cardiovascular risk factors }\end{array}$ & $\begin{array}{l}\text { Motor exhaust (measured } \\
\text { using the dosage of carbon } \\
\text { monoxide exposition) }\end{array}$ & $1.21(0.92-1.59)$ \\
\hline $\begin{array}{l}\text { Burstyn, } \\
2005 \text { [13] }\end{array}$ & $\begin{array}{l}\text { Male asphalt } \\
\text { workers }\end{array}$ & General population & $\begin{array}{l}\text { Age, calendar period, duration of } \\
\text { employment, country }\end{array}$ & $\begin{array}{l}\text { Polycyclic aromatic } \\
\text { hydrocarbons }\end{array}$ & $1.64(1.13-2.38)$ \\
\hline $\begin{array}{l}\text { Toren, } 2007 \\
{[18]}\end{array}$ & $\begin{array}{l}\text { Male } \\
\text { construction } \\
\text { workers }\end{array}$ & White collar workers & $\begin{array}{l}\text { Age, hypertension, smoking and } \\
\text { body mass index }\end{array}$ & $\begin{array}{l}\text { Fumes, diesel exhaust and } \\
\text { asphalt fumes }\end{array}$ & $1.13(1.07-1.19)$ \\
\hline $\begin{array}{l}\text { Bigert, } 2007 \\
\text { [20] }\end{array}$ & Subway drivers & Gainfully employer & Calendar year, age & Air particulate & $0.92(0.68-1.25)$ \\
\hline
\end{tabular}

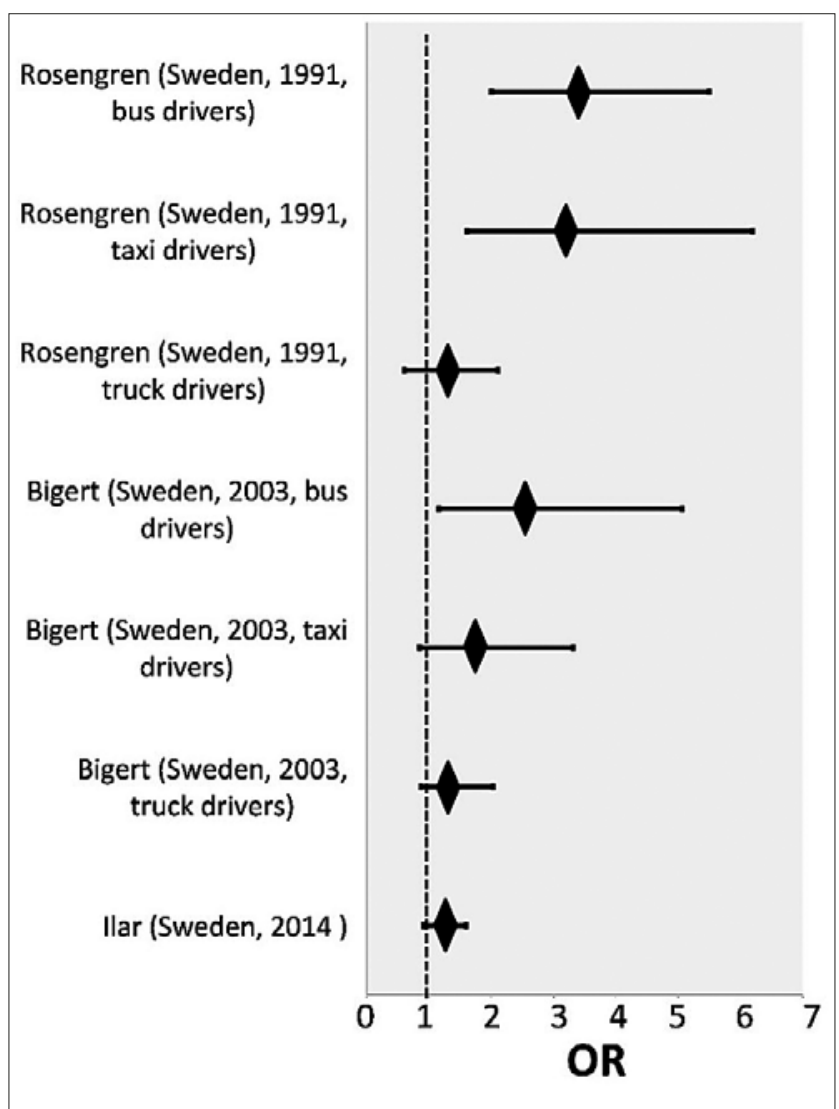

Figure 3. Forest plot of effect estimate of retrospective studies. OR - Odds ratio

\section{DISCUSSION}

The findings of the presented systematic review suggest a possible linkage between occupational exposure to urban air pollution, especially to motor exhaust and particulate, and ischemic heart disease. The most important occupational exposed group to air pollution consists of professional drivers, with particular significance for urban drivers, such as taxi and bus drivers. The most relevant results are the consequence of the prospective studies which examined different types of professional expositions. These results are also probably correlated with the socioeconomic status and the life style of the examined exposed group. These groups are composed of subjects with a sedentary life, unhealthy eating habits and high level of stress. However, it cannot be excluded that the occupational exposition to urban air pollution is an important risk cofactor for ischemic heart disease.

The authors admit that this systematic review is not without limitations and potential biases. Analyzing the biases, it can be asserted that some of them are common to systematic reviews in general. For example, publication bias, which is the tendency for manuscripts with positive findings to be published more than those with negative or null results. However, in the presented review, publication bias was not the most important concern. Of greater concern were the biases and confounding factors inherent in the individual studies, for example, a wide range of exposure assessment methods was used in the different studies, with directly measuring PM or other pollutants in the workplaces. This resulted in the lack of quantitative and qualitative exposure measurements in every study, with the exception of one, where the exposition to carbon monoxide was controlled [17].

Unlike ambient air pollution studies, which can utilize routinely collected environmental monitoring data to study large populations with similar expositions, occupational cohort studies are limited to smaller populations with variable exposure levels, depending on many factors, like tasks, workplace practices and technical controls. In occupational studies, exposures are often difficult to estimate and are assigned to a study cohort by job title. This can lead to exposure misclassification. Another concern is relative to the effect on healthy workers, especially in population mortality and morbility studies, which can be a protective association when healthy workers are compared to those that also include ill people. 
Tabble 3. Effect estimate of retrospective studies. OR - Odds Ratio; CI - Confidential Interval

\begin{tabular}{|c|c|c|c|c|c|}
\hline Reference & Occupational group examined & $\begin{array}{l}\text { External } \\
\text { comparison group }\end{array}$ & Population characteristics standardized to & Exposure type & $\begin{array}{l}\text { Incidence of ischemic heart } \\
\text { disease and/or Myocardial } \\
\text { infarction -OR }(95 \% \mathrm{Cl})\end{array}$ \\
\hline $\begin{array}{l}\text { Rosengren, } \\
1991(16)\end{array}$ & Male bus drivers & $\begin{array}{l}\text { Men in other } \\
\text { occupation group }\end{array}$ & Age and all cardiovascular risk factors & Air pollution & $3.3(2.0-5.5)$ \\
\hline $\begin{array}{l}\text { Rosengren, } \\
1991(16)\end{array}$ & Male taxi drivers & $\begin{array}{l}\text { Men in other } \\
\text { occupation group }\end{array}$ & Age and all cardiovascular risk factors & Air pollution & $3.1(1.6-6.2)$ \\
\hline $\begin{array}{l}\text { Rosengren, } \\
1991(16)\end{array}$ & Male truck drivers & $\begin{array}{l}\text { Men in other } \\
\text { occupation group }\end{array}$ & Age and all cardiovascular risk factors & Air pollution & $1.2(0.6-2.1)$ \\
\hline $\begin{array}{l}\text { Bigert, } \\
2003(13)\end{array}$ & Professional bus drivers & $\begin{array}{l}\text { General } \\
\text { population }\end{array}$ & $\begin{array}{l}\text { Socioeconomic status, tobacco smoking, } \\
\text { alcohol drinking, physical inactivity, } \\
\text { overweight status, diabetes and hypertension }\end{array}$ & Motor exhaust & $2.41(1.15-5.06)$ \\
\hline $\begin{array}{l}\text { Bigert, } \\
2003(14)\end{array}$ & Professional taxi drivers & $\begin{array}{l}\text { General } \\
\text { population }\end{array}$ & $\begin{array}{l}\text { Socioeconomic status, tobacco smoking, } \\
\text { alcohol drinking, physical inactivity, } \\
\text { overweight status, diabetes and hypertension }\end{array}$ & Motor exhaust & $1.64(0.84-3.31)$ \\
\hline $\begin{array}{l}\text { Ilar, } 2014 \\
(21)\end{array}$ & $\begin{array}{l}\text { Professional drivers, garage workers, } \\
\text { construction machine operators }\end{array}$ & $\begin{array}{l}\text { General } \\
\text { population }\end{array}$ & $\begin{array}{l}\text { Sex, age, year of enrollment, diabetes, physical } \\
\text { inactivity, smoking, hypertension, alcohol } \\
\text { drinking and overweight }\end{array}$ & Motor exhaust & $1.21(0.91-1.59)$ \\
\hline
\end{tabular}

Despite these limitations, the collective results from many studies show a positive association between the occupational exposure to air pollution, especially to motor exhaust, and the incidence of ischemic heart disease. No occupational studies about ischemic cardiovascular disease and air pollution were found between the years 2015-2016. Future studies should therefore attempt to overcome the limitations described above. Furthermore, in order to overcome the healthy worker effect, in future studies the authors hope to make a comparison with relatively healthy people selected from among the general population.

\section{REFERENCES}

1. Mendis S, Puska P. Global Atlas on Cardiovascular Disease Prevention and Control. Norrving B editors. World Health Organization, Geneva 2011.

2. Brook RD, Rajagopalan S, Pope CA III, Brook JR, Bhatnagar A, DiezRoux AV, Holguin F, Hong Y, Luepker Rv, Mittleman MA, Peters A, Siscovick D, Smith SC Jr, Whitsel L, Kaufman JD. Particulate matter air pollution and cardiovascular disease: an update to the scientific statement from the America Heart Association. Circulation 2010; 121: 2331-2378.

3. Diane R, Gold MD, Samet JM. Air pollution, climate and hearth disease. Circulation, 2013: 128: e411-e414.

4. Pope III CA, Burnett RT, Thurston G.D, Thun MJ, Calle EE, Krewski D, Goldeski JJ. Cardiovascular mortality and long term exposure to particulate air pollution: epidemiological evidence of general pathophysiological pathways of disease. Circulation 2004; 109: 71-77.

5. Riediker M, Cascio WE, Griggs TR, Herbst MC, Bromberg PA, Neas L, Williams RW, Devlin RB. Particulate matter exposure in cars in associated with cardiovascular effects in healthy young men. Am J Respir Crit Care Med. 2004; 169: 934-940.

6. Baccarelli AA, Byun HM. Platelet mitochondrial DNA methylation: a potential new marker of cardiovascular disease. Clin Epigenetics. 2015 Apr 16; 7(1): 44.

7. Rodosthenous RS, Coull BA, Lu Q, Vokonas PS, Schwartz JD, Baccarelli AA. Ambient particulate matter and microRNAs in extracellular vesicles: a pilot study of older individuals. Part Fibre Toxicol. 2016 Mar 8; 13(1): 13.

8. Panni T, Mehta AJ, Schwartz JD, Baccarelli AA, Just AC, Wolf K, Wahl S, Cyrys J, Kunze S, Strauch K, Waldenberger M, Peters A. A Genome-Wide Analysis of DNA Methylation and Fine Particulate Matter Air Pollution in Three Study Populations: KORA F3, KORA F4, and the Normative Aging Study. Environ Health Perspect. 2016 Jul; 124(7): 983-90.
9. Zhong J, Agha G, Baccarelli AA. The Role of DNA Methylation in Cardiovascular Risk and Disease: Methodological Aspects, Study Design, and Data Analysis for Epidemiological Studies. Circ Res. 2016 Jan 8; 118(1): 119-31.

10. De Marchis P, Tranchina E, Tranchina G, Schillaci S, Verso MG, Picciotto D. Benzene low dose exposure: comparison of different biologic markers among exposed workers and the general population. G Ital Med Lav Ergon. 2007 Jul-Sep; 29(3 Suppl): 528-9.

11. Verso MG, Torretta R, Provenzani A, De Marchis P, Lacca G, Picciotto D. Occupational exposure to environmental pollution: observational study about a newspaper-agents group. G Ital Med Lav Ergon. 2007 Oct-Dec; 29(4): 890-3.

12. Moher D, Liberati A, Tetzlaff J, Altman DG, The PRISMA Group. Preferred Reporting Items for Systematic Reviews and Meta-Analyses: The PRISMA Statement. BMJ 2009; 339: b2535.

13. Burstyn I, Kromhout H, Partanen T, Svane O, Langrad S, Ahrens W, Kauppinen T, Stucker I, Saham J, Heederick D, Ferro G, Heikkila P, Hooiveld M, Johansen C, Randem BG, Boffetta P. Polycyclic aromatic hydrocarbons and fatal ischemic heart disease. Epidemiology 2005; 16: 744-750.

14. Bigert C, Gustavsson P, Hallqvist J, Hogstedt C, Lewnè M, Plato N, Reuterwall C, Schèele P. Myocardial infarction among professional drivers. Epidemiology 2003; 14: 333-339.

15. Gustavsson P, Alfredsson L, Brunneberg H, Hammar N, Jakobsson $\mathrm{R}$, Reuterwall C, Ostlin P. Myocardial infarction among bus, taxi and lorry drivers in middle Sweden. Occup Environ Med. 1996; 53: 235-240.

16. Rosengren A, Anderson K, Wilhelmsen L. Risk of coronary heart disease in middle-aged mal bus and tram drivers ompared to men in other occupations: a prospective study. Int J Epidemiol. 1991; 20(1): $82-87$.

17. Gustavsson P, Plato N, Hallqvist J, Hogstedt C, Lewnè M, Reuterwall C, Schèele P. A population-based case-referent study of myocardial infarction and occupational exposure to motor exhaust, other combustion products, organic solvents, lead and dynamite. Epidemiology. 2001 Mar 12; (2):2, 21-28.

18. Torèn K, Bergdahl IA, Nilsson T, Jarvholm. Occupational exposure to particulate air pollution and mortality due to ischaemic heart disease and cerebrovascular disease. Occup Environ Med. 2007; 64: 515-519.

19. Alfredsson L, Hammar N, Hogstedt C. Inicdence of myocardial infarction and mortality from scientific causes among bus drivers in Sweden. Int J Epidemiol. 1993; 22: 57-61.

20. Bigert C, Klerdal K, Hammar N, Gustavsson P. Myocardial infarction in Swedish subway drivers. Scand J Work Environ Health. 2007; 33(4): 267-271.

21. Ilar A, Lewné M, Plato N, Hallqvist J, Alderling M, Bigert C, Hogstedt C, Gustavsson P. Myocardial infarction and occupational exposure to motor exhaust: a population-based case-control study in Sweden. Eur J Epidemiol. 2014; 29: 517-525. 